LA-14284

Approved for public release;

distribution is unlimited.

Concentration Ratios for Cesium and Strontium in Produce Near Los Alamos 
Edited by Hector Hinojosa, Group IM-1

Los Alamos National Laboratory, an affirmative action/equal opportunity employer, is operated by the University of California for the United States Department of Energy under contract W-7405-ENG-36.

This report was prepared as an account of work sponsored by an agency of the United States Government. Neither the Regents of the University of California, the United States Government nor any agency thereof, nor any of their employees make any warranty, express or implied, or assume any legal liability or responsibility for the accuracy, completeness, or usefulness of any information, apparatus, product, or process disclosed, or represent that its use would not infringe privately owned rights. Reference herein to any specific commercial product, process, or service by trade name, trademark, manufacturer, or otherwise does not necessarily constitute or imply its endorsement, recommendation, or favoring by the Regents of the University of California, the United States Government, or any agency thereof. The views and opinions of authors expressed herein do not necessarily state or reflect those of the Regents of the University of California, the United States Government, or any agency thereof. Los Alamos National Laboratory strongly supports academic freedom and a researcher's right to publish; as an institution, however, the Laboratory does not endorse the viewpoint of a publication or guarantee its technical correctness. 
LA-14284

Issued: March 2006

Concentration Ratios for Cesium and Strontium in Produce Near Los Alamos

Sophia Salazar

Mike McNaughton

P.R. Fresquez 



\title{
Concentration Ratios for Cesium and Strontium in Produce Near Los Alamos
}

by

\author{
Sophia Salazar, Mike McNaughton, P.R. Fresquez
}

\begin{abstract}
The ratios of the concentrations of radionuclides in produce (fruits, vegetables, and grains) to the concentrations in the soil have been measured for cesium and strontium at locations near Los Alamos. The Soil, Foodstuffs, and Biota Team of the Meteorology and Air Quality Group of the Los Alamos National Laboratory (LANL) obtained the data at locations within a radius of 50 miles of LANL. The concentration ratios are in good agreement with previous measurements: 0.01 to 0.06 for cesium-137 and 0.1 to 0.5 for strontium-90 (wet-weight basis).
\end{abstract}

\section{Introduction}

Concentration ratios are the ratios of the concentrations of radionuclides in biota to the concentrations in the underlying media such as the soil. They are important for the biota dose assessments directed by the US Department of Energy (DOE) Standard (DOE 2002). In the DOE Standard and its supporting computer program, RESRAD-BIOTA, the concentration ratios are called "bioaccumulation factors" (abbreviated $B_{i v}$ or BIV) or "lumped parameters." In other publications, similar quantities are called "concentration factors" (Eisenbud and Gesell, 1997; Till and Meyer, 1983) or transfer factors (Till and Meyer, 1983). Some of these are calculated on the basis of wet, dry, or ash weight, so caution is needed. For use with RESRAD-BIOTA, concentration ratios in this paper are converted to a wet-weight basis.

In the DOE Standard (DOE 2002) the default bioaccumulation factors for cesium and strontium are greater than one. For example, on page M3-45, Table 3.2C, the DOE Standard lists a value of 100 for cesium and 76 for strontium. These results are derived from the worst cases reported in Tables 5.17 or 5.41 of Till and Meyer (1983). Values greater than one were measured in soils deficient in calcium or potassium (e.g., Savannah River or Florida) and are unlikely to apply to soils near Los Alamos. (For potassium or calcium concentrations, see http://energy.cr.usgs.gov/radon/DDS-9.html and http://tin.er.usgs.gov/geochem/doc/averages/ca/usa.html)

For the purpose of biota dose assessment, the first objective is to determine if the concentration ratios for cesium and strontium are less than one for the following reason. The biota dose is the sum of the external dose (from radionuclides outside the biota) and internal dose (from radionuclides inside the biota.) If the concentration ratio is less than or equal to one, the worst case is the total immersion dose, which is calculated using 
Table 2.4 on page M3-18 of the DOE Standard. This calculation assumes the biota are much smaller than the range of the gamma and beta radiation, so the internal concentration does not matter provided it is no more than the external concentration.

Bioaccumulation takes place in steps, as each trophic level increases the concentration. According to Whicker and Schultz (1982), a typical factor for each trophic level is three. Therefore, if the concentration ratio for plants is less than 0.3 there is reasonable assurance that the concentration ratio for mice is less than one, and if the concentration ratio for plants is less than 0.1 there is reasonable assurance that it is less than one for predators.

\section{Concentrations in produce}

Extensive measurements of radionuclides in produce (fruits, vegetables, and grains) have been reported for the calendar years 1978 through 2004 in the annual environmental surveillance reports (for a full list of environmental surveillance report numbers, refer to the appendix). The produce was collected from a variety of locations within 50 miles of Los Alamos National Laboratory (LANL), washed, dried, and analyzed as described in procedures ENV-MAQ-701, -706, -711, and -712. Generally, concentrations are reported on a dry-weight basis and were converted to wet weight using the average dry-/wetweight ratio of 0.13 obtained from Fresquez et al. (2004).

The data were averaged by year, by location, and by type of produce, using both simple and weighted means, and were generally consistent with wet-weight cesium-137 concentrations $<0.0006 \mathrm{pCi} / \mathrm{g}$ and strontium-90 concentrations $<0.005 \mathrm{pCi} / \mathrm{g}$.

\section{Concentrations in soil}

The soil data were obtained from a variety of locations within 50 miles of LANL and reported in the annual environmental surveillance reports. A summary of the data from 1974 through 1994 was reported in Fresquez et al. (1996). In Table 1 of Fresquez et al. (1996), the average regional concentrations were reported to be $0.43 \pm 0.35 \mathrm{pCi} / \mathrm{g}$ for cesium-137 and $0.32 \pm 0.25 \mathrm{pCi} / \mathrm{g}$ for strontium-90. A more recent average, using simple means and including the data through 2003 , is $0.38 \pm 0.32 \mathrm{pCi} / \mathrm{g}$ for cesium-137 and 0.28 $\pm 0.21 \mathrm{pCi} / \mathrm{g}$ for strontium-90. These results are consistent within the factor-of-two accuracy desired for the present investigation.

The soil concentrations are averaged for the top $5 \mathrm{~cm}$ of soil, whereas the plant roots generally penetrate deeper than $5 \mathrm{~cm}$. In order to calculate an upper limit for the ratios, we assume that the roots penetrate to $30 \mathrm{~cm}$; so we assume the average concentration sampled by the roots is $5 / 30$ times the measured concentration, i.e., $0.06 \mathrm{pCi} / \mathrm{g}$ for cesium-137 and $0.05 \mathrm{pCi} / \mathrm{g}$ for strontium- 90 . This is a conservative assumption designed to produce an upper limit for the concentration ratio. 


\section{Radioactive decay}

Radioactive decay causes both the soil and the plant concentrations to decrease with time and therefore cancels to first order. The soil and plant data do not cover exactly the same time interval, but the differences are negligible. If the data from before 1980 are excluded, the soil averages are $0.37 \pm 0.32 \mathrm{pCi} / \mathrm{g}$ for cesium- 137 and $0.26 \pm 0.21 \mathrm{pCi} / \mathrm{g}$ for strontium-90, which are consistent with the averages for all data: $0.38 \pm 0.32 \mathrm{pCi} / \mathrm{g}$ for cesium-137 and $0.28 \pm 0.21 \mathrm{pCi} / \mathrm{g}$ for strontium- 90 .

\section{Concentration ratio}

The concentration ratio is the ratio of the concentration in the produce to the concentration in the soil.

For cesium-137 it is less than $(0.0006 \mathrm{pCi} / \mathrm{g}) /(0.06 \mathrm{pCi} / \mathrm{g})=0.01$

For strontium- 90 it is less than $(0.005 \mathrm{pCi} / \mathrm{g}) /(0.05 \mathrm{pCi} / \mathrm{g})=0.1$

These results are consistent with the results reported previously by Fresquez et al. (1997), White et al. (1981), and Hakonson et al. (1973): 0.01 to 0.06 for cesium-137 and 0.1 to 0.5 for strontium-90 (wet-weight basis). The data reported in Bennett et al. (1996), Fresquez and Gonzales (2004), Hakonson and Bostick (1975), and Miera and Hakonson (1978) are not suitable for a direct calculation of the concentration ratios, but they are generally consistent with the ratios reported above.

\section{Errors and uncertainties}

The uncertainties are greater than a factor of two. Where uncertainties have been identified, the largest numerators and smallest denominators have been chosen, so the concentration ratios calculated here are upper limits. For example, the average root depth depends on the depth of tilled soil, which could be less than the assumed value of $30 \mathrm{~cm}$, in which case the true soil concentration would be larger and the ratio would be smaller. Furthermore, some of the cesium-137 and strontium- 90 could be deposited on the surface of the plant instead of absorbed into the plant. This would happen if rain or irrigation splashes soil onto the surface of the plant and is not completely washed off. In this case, the true plant concentration would be smaller and the ratio would be smaller.

Therefore, the concentration ratios reported above are reasonable estimates of the upper limits.

\section{Conclusion}

The data show that the concentration ratios for cesium-137 and strontium- 90 are much smaller than one. Therefore, for the purpose of biota dose assessment as described in the DOE Standard (DOE 2002), the dose is best estimated using the coefficients for external dose as listed in Table 2.4 on page M3-18 of the Standard. 


\section{References}

Bennett, K., J. Biggs, and P. Fresquez, "Radionuclide Contaminant Analysis of Small Mammals, Plants, and Sediments within Mortandad Canyon, 1994," Los Alamos National Laboratory report LA-13104-MS (1996).

DOE, "A Graded Approach for Evaluating Radiation Doses to Aquatic and Terrestrial Biota," US Department of Energy Standard DOE-STD-1153-2002 (2002).

Eisenbud, M. and T. Gesell, Environmental Radioactivity, Academic Press (1997).

Fresquez, P.R., M.A. Mullen, J.K. Ferenbaugh, and R.A. Perona, "Radionuclides and Radioactivity in Soils Within and Around Los Alamos National Laboratory, 1974 through 1994, Concentrations, Trends, and Dose Comparisons," Los Alamos National Laboratory report LA-13149-MS (1996).

Fresquez, P.R., D.R. Armstrong, M.A. Mullen, and L. Naranjo, Jr., "Radionuclide Concentrations in Pinto Beans, Sweet Corn, and Zucchini Squash Grown in Los Alamos Canyon at Los Alamos National Laboratory," Los Alamos National Laboratory report LA-13304-MS (1997).

Fresquez, P.R. and G.J. Gonzales, "Radionuclide Concentrations in Vegetation at the Los Alamos National Laboratory in 2002/2003," Los Alamos National Laboratory report LA14160-PR (2004).

Fresquez, P.R., J.K. Ferenbaugh, and L. Naranjo, Jr., "Moisture Conversion Ratios for the Foodstuffs and Nonfoodstuffs Biota Environmental Surveillance Programs at LANL," Los Alamos National Laboratory report LA-UR-04-4122 (2004).

Hakonson, T.E., J.W. Nyhan, L.J. Johnson, and K.V. Bostick "Ecological Investigation of Radioactive Materials in Waste Discharge Areas at Los Alamos," Los Alamos Scientific Laboratory report LA-5282-MS (1973).

Hakonson, T.E. and K.V. Bostick, "Cesium-137 and Plutonium in Liquid Waste Discharge Areas at Los Alamos," in Radioecology and Energy Resources, Proceedings of the Fourth National Symposium on Radioecology, edited by Colbert E. Cushing, Jr., and published by Dowden, Hutchingon, and Ross (1975).

Miera, F.R. and T.E. Hakonson, "Radiation Dose to Rodents Inhabiting a Radioactive Waste Receiving Area," Health Physics 34:603-609 (1978).

Till, J.E. and H.R. Meyer, "Radiological Assessment," US Nuclear Regulatory Commission report NUREG/CR-3332 (1983). 
Whicker, F.W. and V. Schultz, Radioecology: Nuclear Energy and the Environment, CRC Press (1982).

White, G.C., T.E. Hakonson, and A.J. Ahlquist, "Factors Affecting Radionuclide Availability to Vegetables Grown at Los Alamos," Journal of Environmental Quality 10:294-299 (1981). 
Appendix: Report Identification Numbers for Annual Environmental Surveillance Reports

\begin{tabular}{|c|c|c|c|}
\hline Year & Report Number & Year & Report Number \\
\hline 1959 & LAMS-2397 & 1982 & LA-9762-ENV \\
\hline 1960 & LAMS-2499 & 1983 & LA-9349-ENV \\
\hline 1961 & LAMS-2702 & 1984 & LA-10421-ENV \\
\hline 1962 & LAMS-2870 & 1985 & LA-10721-ENV \\
\hline 1963 & LAMS-3071 & 1986 & LA-10992-ENV \\
\hline 1964 & LA-3245-MS & 1987 & LA-11306-ENV \\
\hline 1965 & LA-3516 & 1988 & LA-11628-ENV \\
\hline 1966 & LA-3663 & 1989 & LA-12000-ENV \\
\hline 1967 & LA-3887 & 1990 & LA-12271-ENV \\
\hline 1968 & LA-4133 & 1991 & LA-12572-ENV \\
\hline 1969 & LA-4388 & 1992 & LA-12764-ENV \\
\hline 1970 & $\begin{array}{l}\text { LA-4661 and } \\
\text { LA-4672-MS }\end{array}$ & 1993 & LA-12973-ENV \\
\hline 1971 & $\begin{array}{c}\text { LA-4871-MS and } \\
\text { LA-4970 }\end{array}$ & 1994 & LA-13047-ENV \\
\hline 1972 & $\begin{array}{c}\text { LA-5097-MS and } \\
\text { LA-5184 }\end{array}$ & 1995 & LA-13210-ENV \\
\hline 1973 & LA-5586 & 1996 & LA-13343-ENV \\
\hline 1974 & LA-5977-PR & 1997 & LA-13487-ENV \\
\hline 1975 & LA-6321-MS & 1998 & LA-13633-ENV \\
\hline 1976 & LA-6801-MS & 1999 & LA-13775-ENV \\
\hline 1977 & LA-7263-MS & 2000 & LA-13861-ENV \\
\hline 1978 & LA-7800-ENV & 2001 & LA-13979-ENV \\
\hline 1979 & LA-8200-ENV & 2002 & LA-14085-ENV \\
\hline 1980 & LA-8810-ENV & 2003 & LA-14162-ENV \\
\hline 1981 & LA-9349-ENV & 2004 & LA-14239-ENV \\
\hline
\end{tabular}


This report has been reproduced directly from the best available copy. It is available electronically on the Web (http://www.doe.gov/bridge).

Copies are available for sale to U.S. Department of Energy employees and contractors from:

Office of Scientific and Technical Information P.O. Box 62

Oak Ridge, TN 37831

(865) 576-8401

Copies are available for sale to the public from: National Technical Information Service

U.S. Department of Commerce

5285 Port Royal Road

Springfield, VA 22161

(800) 553-6847 


\section{Los Alamos}

NATIONAL LABORATORY

EST.1943 